\title{
EVALUATION OF OPTIMAL ECOLOGICAL TOURISM ROUTES OBTAINED VIA GOOGLE EARTH SOFTWARE IN AN ENVIRONMENTAL PROTECTION AREA
}

\author{
Carlos Alberto Araújo Júnior ${ }^{1 *}$, Paulo Ricardo Santos Miranda ${ }^{2}$, Thais Sales Gonçalves ${ }^{3}$, Sthefany Mendes \\ Zuba $^{4}$, Renato Vinícius Oliveira Castro ${ }^{5}$, Gustavo Eduardo Marcatti ${ }^{6}$ \\ ${ }^{1 *}$ Federal University of Minas Gerais, Institute of Agricultural Sciences, Montes Claros, Minas Gerais, Brazil - carlosaraujo@ufmg.br \\ ${ }^{2}$ Federal University of Minas Gerais, Institute of Agricultural Sciences, Montes Claros, Minas Gerais, Brazil - ricarddosm@ hotmail.com \\ ${ }^{3}$ Federal University of Minas Gerais, Institute of Agricultural Sciences, Montes Claros, Minas Gerais, Brazil - thaiswj@ gmail.com \\ ${ }^{4}$ Federal University of Minas Gerais, Institute of Agricultural Sciences, Montes Claros, Minas Gerais, Brazil - sthefanyzuba@gmail.com \\ ${ }^{5}$ Federal University of São João del-Rei, Department of Forest Engineering, Sete Lagoas, Minas Gerais, Brazil - castrorvo@ymail.com \\ ${ }^{6}$ Federal University of São João del-Rei, Department of Forest Engineering, Sete Lagoas, Minas Gerais, Brazil - \\ gustavomarcatti@ufsj.edu.br
}

Received for publication: 14/05/2020 - Accepted for publication: 27/08/2020

\begin{abstract}
Resumo
Avaliação de rotas ótimas para ecoturismo obtidas com o software Google Earth em uma área de proteção ambiental. $\mathrm{O}$ ecoturismo se destaca como uma atividade econômica que pode ser conciliada com a conservação da natureza. Tal atividade tem sido realizada em diversas unidades de conservação no Brasil. Entretanto, para que isso aconteça de maneira satisfatória, é necessário um planejamento adequado acerca das atividades que podem ser realizadas, dos locais que podem ser visitados e dos trajetos que podem ser feitos para alcançar tais locais. Nesse sentido, buscou-se avaliar se o software Google Earth pode auxiliar na elaboração do plano de utilização dessas áreas, principalmente em relação ao percurso que poderá ser feito pelos turistas dentro da unidade de conservação. Para isso, foram definidos os locais de interesse turístico na Área de Proteção Ambiental Estadual do Rio Pandeiros, região norte do estado de Minas Gerais. A partir de tais pontos, foram avaliadas as rotas de menor distância entre pares de locais obtidas com o software Google Earth e com o software QGIS. Para o segundo caso, foi necessário realizar a vetorização e classificação de todas as estradas do local. Comparou-se os comprimentos dos trajetos obtidos com os dois softwares a partir de um teste de identidade de métodos. Os resultados mostraram que, para a maioria das rotas, o Google Earth apresentou caminhos mais longos que o QGIS. Pode-se concluir que um planejamento mais preciso para fins de ecoturismo deve considerar a vetorização das estradas em locais onde há uma grande quantidade de estradas rurais. Ainda, conclui-se que o local apresenta uma grande variedade de atrativos para o ecoturismo.

Palavras-chave: Geoprocessamento; Turismo; Mapeamento; Otimização; Pesquisa Operacional.
\end{abstract}

Abstract
Ecological tourism stands out as an economic activity that can be reconciled with nature conservation. Such
activities have been carried out in several conservation units in Brazil. However, for satisfactory
implementation, it is necessary to effectively plan the activities to be conducted, places to be visited, and paths
to reach those places. In this context, we aimed to assess whether Google Earth software can assist in the
expansion of the plan to use these areas for ecotourism, especially the routes that may be taken by tourists
within the conservation unit. For this purpose, tourist interest sites were defined in the State Environmental
Protection Area of Rio Pandeiros in the northern region of the state of Minas Gerais. The shortest routes
between the pairs of locations obtained using Google Earth and QGIS software were evaluated. Additionally,
it was necessary to perform vectorization and classification of all roads in the area. The lengths of the paths
obtained were compared using a method identity test. The results showed that for most routes, Google Earth
showed longer paths than QGIS. It can be concluded that for the purpose of ecotourism, precise planning should
consider the vectorization of roads in areas with many rural roads.
Keywords: Geoprocessing; Tourism; Mapping; Optimization; Operations Research.

\section{INTRODUCTION}

One of the major challenges in forest science is the search for alternatives to use natural resources without causing significant impacts on the environment. Ecotourism has been highlighted as a possible option for priority environments in terms of ecological protection. It boosts environmental preservation, improves economy of local communities, and promotes environmental conscience in visitants (Hunt et al., 2015).

To develop this activity in a selected region of interest, it is necessary to learn about the local characteristics and make adequate visitation plans. In this context, it is important to consider investing in the tourism priority sectors. This can promote satisfaction with the tourist as expected when they come from their home to visit a place.

Tourism activity is a reality in a wide range of Brazilian conservation units. National Park of Tijuca (Rio de Janeiro State), National Park of Jericoacoara (Ceará State), National Park of Iguaçu (Paraná State), 
Environmental Protection Area of Petrópolis (Rio de Janeiro State), and Arraial do Cabo Marine Extractive Reserve (Rio de Janeiro State) have 2.9, 2.0, 2.0, 1.3, and $1.0 \mathrm{mi}$ of registered visitors, respectively, in 2019 according to the Dynamic Information Panel of Chico Mendes Institute for Biodiversity and Conservation (ICMBio), are highlighted (ICMBio, 2020).

The Rio Pandeiros State Environmental Protection Area (RPSEPA) is the largest conservation unit in Minas Gerais State, located in the northern region of the state. The RPSEPA is an important conservation unit for ichthyofauna in the São Francisco River Basin, due to the fish diversity and local biotic conditions (Santos et al., 2015). An example of its importance is the discovery of a new fish species "cascudo" at Catulé stream, tributary of Pandeiros River, identified as Hisonotus devidei by Roxo et al. (2018).

Martinsa et al. (2020) mentioned that the Pandeiros River Basin presents good ecological conditions and less environmental fragility. Rezende et al. (2012) have already researched water quality in this region, which was found to be excellent; this was also proved by Dantas et al. (2020). They highlighted the importance of a conservation unit for the maintenance of a healthy natural environment. This reinforces the conservative characteristics of the RPSEPA, indicating its potential in ecological tourism activities.

Many studies have considered aspects related to tourism. They show that tourists from distant places, not necessarily from another country, are more inclined to visit several places in a day (Padilla et al., 2018; Xue e Zhang, 2020). Hence, it is necessary that the routes connecting different tourist attractions be known, which are easy to access and short. This can make the visit more pleasant, leaving more time to enjoy the scenery.

These routes can be defined by mapping the roads that exist locally, identifying interesting tourist places, and applying operational techniques to calculate the minimum path between attractions. However, this demands specific technical knowledge, which is lacking in government entities or conservation unit managers. In this case, an alternative is the use of Google Earth (GE) software.

Some scientific papers have demonstrated that GE can contribute to a wide range of fields (Choi and Nieto (2011); Frankl et al. (2013); Jacobson et al. (2015); Malarvizhi et al. (2016); Menezes et al. (2019); Mohammed et al. (2013); Puliche et al. (2016); Webster et al. (2016)). This can be attributed to the fact that GE offers free and high-spatial-resolution images. It is beneficial when it is impossible to invest in either high technologies or resources for measurements in large areas.

The aim of this work was to evaluate the hypothesis that GE can obtain optimal routes that connect different tourist spots, avoiding the use of more complex geographic information systems.

\section{MATERIAL AND METHODS}

\section{Study area}

The Pandeiros River State Environmental Protection Area is located in Januária, Bonito de Minas, and Cônego Marinho municipalities. It is a sustainable use conservation unit, as defined by the National System of Conservation Units. The total area is 393,866 ha, and it is the largest conservation unit of Minas Gerais State. It includes important natural formations, such as waterfalls in the Pandeiros District, wetlands near the São Francisco River, and "veredas" (palm swamp vegetation) located along streams.

The weather is Aw type (Tropical of Savanna), with two well-defined stations and characterized by wet summer and dry winter according to the Köppen-Geiger classification. The average annual temperature ranged between $18.4{ }^{\circ} \mathrm{C}$ and $31.9^{\circ} \mathrm{C}$. The average annual precipitation was $876 \mathrm{~mm}$, according to the data obtained from a meteorological station located in Januária and collected between 1988 and 2018 by the National Institute of Meteorology.

The RPSEPA is composed predominantly of Brazilian savanna (Cerrado sensu strictu) (Fagundes et al., 2019), with highlights for "vereda" areas (Fagundes et al., 2016), grasslands and Mata Seca (Leite et al., 2018). In the south of RPSEPA, there are wetlands with typical vegetation.

\section{Definition of tourist spots}

The tourist spots in RPSEPA were defined considering three sources of information: (I) literature, (II) websites, and (III) field interviews. The repositories Web of Science, Google Scholar, and Scielo were checked for case I, searching exclusively for scientific papers that mentioned the terms "Rio Pandeiros" or "Pandeiros River" in the title, abstract, or keywords. In these papers, references were checked for local areas with evidence of tourist visitation and their coordinates. For case II, websites such as Instagram, Facebook, Picasa, Flickr, Google Maps, and Wikiloc, in addition to the governmental sites of Ministry of the Environment, Ministry of Tourism, and State Forest Institute were consulted. For this case, the study considered posts, photos, reports, and documents about places that could be considered interesting for tourism. For Wikiloc, trails informed by users of mobile app were evaluated. Two field expeditions and interviews with local people were conducted in Case III, where the residents were questioned about places visited by tourists. 
All these locations were mapped with a global navigation satellite system (GNSS) receptor, and their coordinates were inserted in a geographic information system.

\section{Obtaining routes with GE}

GE software was used to obtain the optimal routes between all pairs of tourist spots. It was necessary to indicate the geographic coordinates of the origin and destination in the search field in the software. The text format was "from: latitude, longitude to: latitude, longitude".

The shortest route was selected from the multiple routes presented by the software. All routes were organized and saved in a unique keyhole markup language (KML) file (Choi and Nieto, 2011; Frankl et al., 2013). This file was then imported into the QGIS software for analysis.

\section{Obtaining routes with QGIS}

All roads in the RPSEPA were vectorized to obtain the routes for all the pairs of tourist spots using the QGIS software. This activity was necessary because the conservation unit has a small population with low occupation rate, and not all roads are digitalized and available in government databases. Satellite images with high resolution made available by GE software were used to identify and vectorize the roads.

During the vectorization step, two field visits were conducted to evaluate the current road conditions. Three classes of quality were considered: (I) trafficable, (II) hard access, and (III) non-trafficable. The class I consists of roads commonly used by the local population and does not restrict traffic. They are roads with and without paving. Class II indicates roads with characteristics that harm traffic, such as sandy soils and small width. Class III indicates roads that are visible in satellite images but do not exist or are farm frontiers. Roads considered as class III were not used to define the optimal routes between tourist spots.

All tourist spots were visited to map trails from the road to the local area of observation. This was performed using a GNSS receptor, (Garmin Montana 620 model). These trials were included in road files.

The shortest path algorithm (point-to-point) was used to calculate the optimal routes between pairs of tourist spots using the QGIS software. This algorithm computes the path with the shortest distance between two geographic coordinates and considers the road network from a vector file. A script developed in Python was used to make the processing less exhaustive.

Restriction on directions was not considered, and therefore, all roads allow traffic in two ways. With this, the number of total routes considering all pairs of tourist spots can be calculated using the formula:

$$
\mathrm{n}_{\mathrm{R}}=\frac{\mathrm{n}_{\mathrm{L}} *\left(\mathrm{n}_{\mathrm{L}}-1\right)}{2}
$$

where $n_{R}$ is the total number of routes, and $n_{L}$ is the number of tourist spots.

\section{Evaluation of results}

After calculating the distance of each route obtained from GE and QGIS, route layers were simplified using the algorithm "dissolve." This allowed the evaluation of route network lengths obtained by both the software that connected all tourist spots in the RPSEPA.

A buffer of $20 \mathrm{~m}$ was created around the route network obtained from GE to evaluate the route network overlap. Then, the route network from the QGIS was clipped. The length of the features that resulted from the clipping process was calculated to define the rate of overlap.

The L\&O test (Leite and Oliveira, 2002) was applied to compare the two sets of routes. It evaluates whether the two methods of route definition create results without significant statistical differences. The test is composed of three simultaneous evaluations: (1) an F test to evaluate if the variances are equal; (2) two t-tests to evaluate if the angular and linear coefficients of the equation that regresses one method against another is statistically equal to one and zero, respectively; (3) and a test to evaluate whether the correlation between the methods is larger than a unit minus the percentage of absolute average error. The test is not significant when all three evaluations are not significant, and shows that the methods present statistically identical results.

A dispersion graphic was created to compare the lengths obtained from the two software packages, and a descriptive statistical analysis was performed.

\section{RESULTS}

Thirty-one places of tourist interest were considered in the RPSEPA (Figure 1). They were not concentrated in a single region, but were present within a radius of $54 \mathrm{~km}$ from the center of the conservation unit. Five spas, three waterfalls, one municipal office, three districts, and seventeen other places with potential for tourism were identified. The largest number of attractions was in the region of the District of Pandeiros, which included the resort at the Pandeiros River and three waterfalls. 


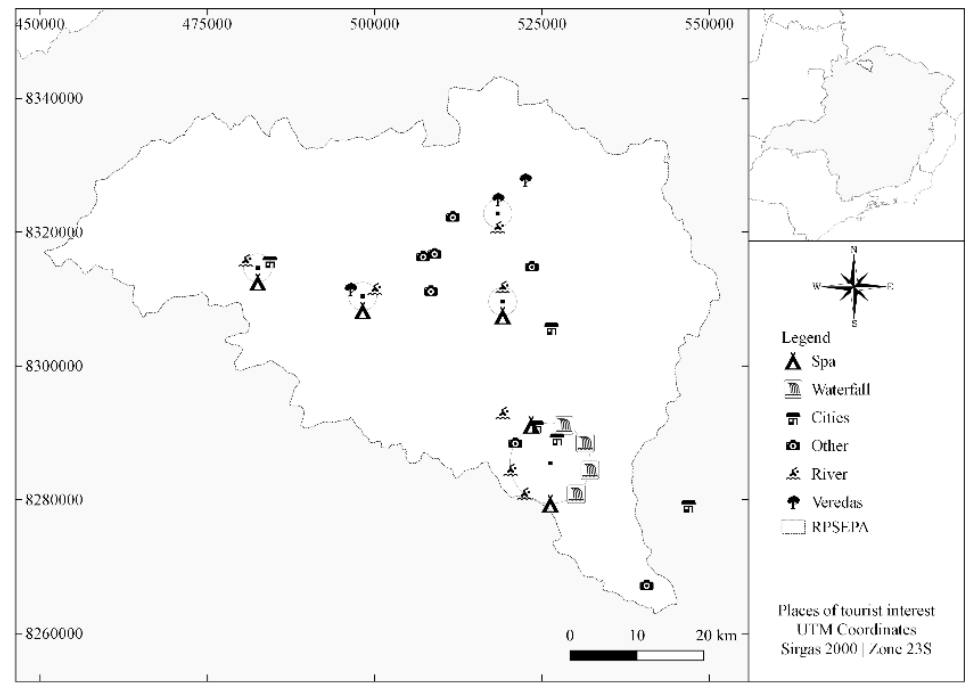

Figure 1. Location of points of tourist interest in the RPSEPA.

Figura 1. Localização dos pontos de interesse turístico na APAERP.

Some of the sites were not yet explored by visitors; there were no infrastructure for the accommodation of tourists, but were susceptible to short visits, as was the case of some "veredas" (Figure 2a) and water streams (Figure 2b). However, the watering places (Figures 2c and 2d) have a minimum structure for comfortable use, as was the case for those near Pandeiros (latitude: -15.5130; longitude: -44.7535), Bonito de Minas (latitude: 15.2895; longitude: -44.8218), Várzea Bonita (latitude: -15.2445; longitude: -45.1612), and Raizama (latitude: 15.4563; longitude: -44.7821).

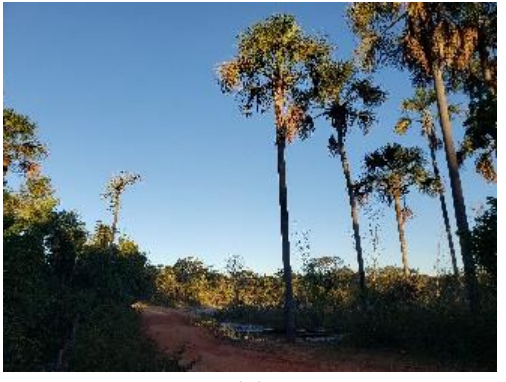

(a)

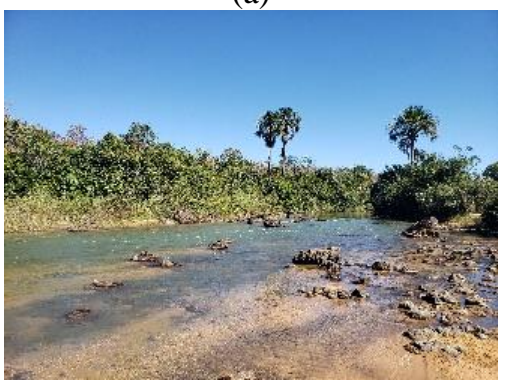

(c)

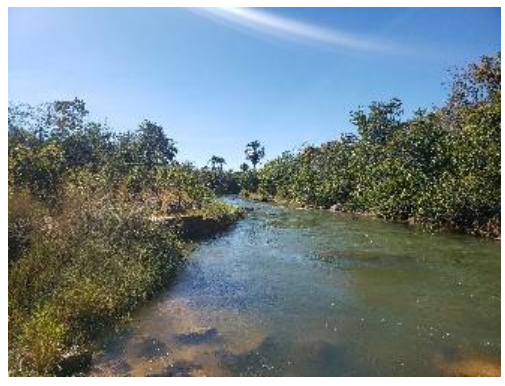

(b)

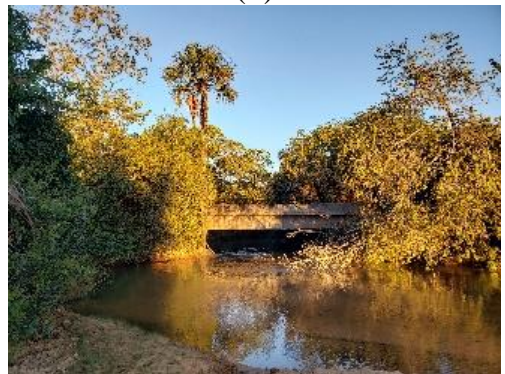

(d)

Figure 2. Examples of wetland (a), stream (b), and bathing place (c and d) in the Rio Pandeiros State Environmental Protection Area.

Figura 2. Exemplos de vereda (a), córrego (b) e balneários (c e d) na Área de Proteção Ambiental Estadual do Rio Pandeiros.

The vectorization and classification of roads showed that 55\% of them were hard-to-reach roads (class II), $27 \%$ were impassable stretches (class III), and $18 \%$ were passable roads (class I) or had low traffic restrictions. Thus, a network of approximately $7,700 \mathrm{~km}$ of roads (classes I and II) were considered, to identify the routes using QGIS software. 
With the mapped locations, 465 routes were built connecting all the pairs of points using GE and QGIS software (Figure 3). Notably, processing with QGIS (Figure 3a) resulted in the use of a larger number of snippets compared to GE (Figure 3b). Moreover, in the case of sites far from the main roads, GE closed the route at a point closest to the exact location of the attraction, which occurred in twelve of the thirty-one locations.
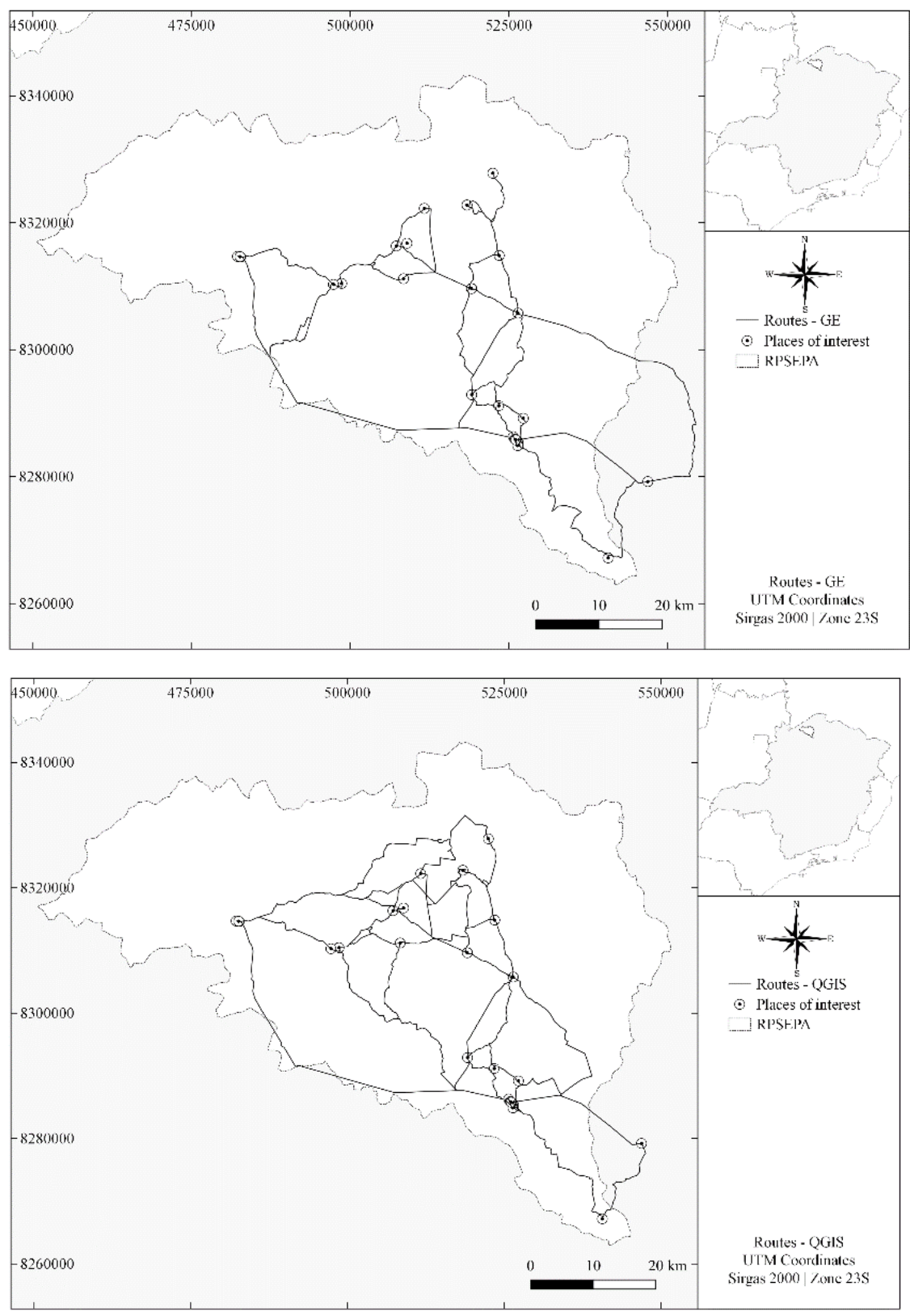

(a)

(b)

Figure 3. Places of tourist interest in the Rio Pandeiros State Environmental Protection Area and routes obtained from Google Earth (a) and QGIS (b).

Figura 3. Localização dos pontos de interesse turístico na APAERP e rotas obtidas pelo Google Earth (a) e pelo QGIS (b).

On an average, the routes obtained from GE were longer than those obtained using the QGIS software (Table 1). However, the road network processed by GE was smaller than that of QGIS. From a total of $428.88 \mathrm{~km}$ of the road network used by GE to connect the places of tourist interest, approximately $231 \mathrm{~km}$ of the road network was also indicated by QGIS software. The use of the same route by both software occurred in approximately $34 \%$ of the routes, with small variations in the total distance of each route depending on the positioning of the roads considered in each system. For $63 \%$ of routes, GE had a longer route than QGIS. 
Table 1. Descriptive statistics of routes obtained with Google Earth and QGIS software.

Tabela 1. Estatística descritiva das rotas obtidas com os softwares Google Earth e QGIS.

\begin{tabular}{crr}
\hline Parameter & Google Earth & QGIS \\
\hline Longest route length $(\mathrm{km})$ & 102.11 & 91.61 \\
Average route length $(\mathrm{km})$ & 39.97 & 34.73 \\
Total route length $(\mathrm{km})$ & $18,585.29$ & $16,151.71$ \\
Road network length $(\mathrm{km})$ & 428.88 & 538.87 \\
Number of longest routes (over 1 km of difference) & 291 & 17 \\
Number of routes of similar length (less than 1 km difference) & 157 & 157 \\
Percentage of road network overlap & 53.8 & 42.9 \\
\hline
\end{tabular}

The L\&O test showed that the methods for obtaining optimal routes between the points of tourist interest present statistically different results. The correlation between the values obtained with QGIS and the values obtained with GE was $96.20 \%$, which can be considered high. However, the linear coefficient of 0.6988 and the angular coefficient of 1.1305 were statistically different from 0 (p-value $<0.01$ ) and 1 (p-value $<0.01$ ), which indicated the rejection of the null hypothesis of the L\&O test in its second evaluation. The F test also showed a significant result $(\mathrm{p}<0.01)$. Furthermore, the routes obtained with QGIS were mostly shorter than those obtained by GE (Figure 4), with a great variation for routes with lengths above $30 \mathrm{~km}$. The mean absolute percentage error was equal to $16.18 \%$.

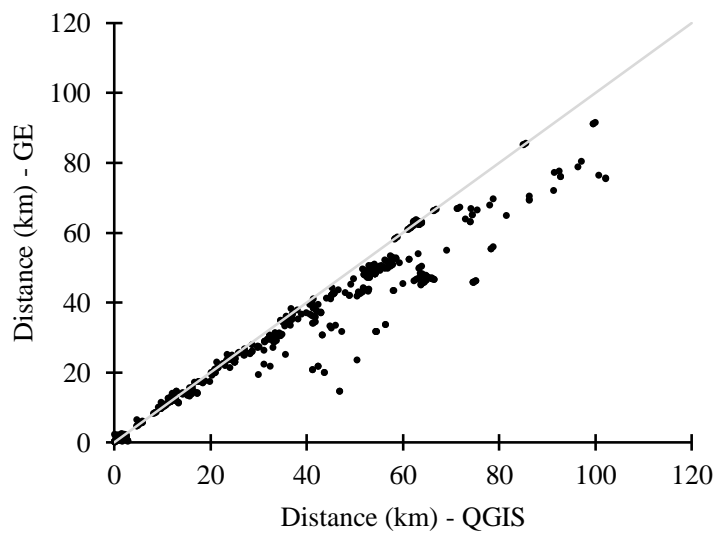

Figure 4. Graph comparing route lengths obtained from Google Earth and QGIS software.

Figura 4. Gráfico de dispersão comparando as distâncias das rotas obtidas com os softwares Google Earth e QGIS.

\section{DISCUSSION}

The RPSEPA presents tourist potential due to the presence of various attractions such as "veredas," waterfalls, watering places, hills, and a large, flooded area known as "Pantanal Mineiro." However, the RPSEPA is located in a region with serious social problems and requires large public investments, which has not occurred in recent years.

An alternative for the sustainable use of conservation units is ecological tourism, which aims to increase the income of local communities without negatively impacting the environment. In this sense, defining the routes for tourists to transit between places of interest becomes important, which allows public and private entities to plan the investments to promote tourist activity in RPSEPA.

An issue that needs to be included in the planning of tourist exploration is making the arrangements for tourists to arrive at their destinations. Xue and Zhang (2020) mentioned that improving the passenger transport system facilitates increased travel between cities in China. In the case of RPSEPA, this aspect can be considered by investing in road maintenance and constructing transport lines between tourist spots. Therefore, studies focusing on defining the optimal ecotourism routes should be promoted.

The use of GE in situations that necessitate the indication of optimal routes has been the subject of other research, such as the works of Lukongo and Miller (2018), and Sirirak and Pitakaso (2018). GE is a free software that requires little training, has a relatively short processing time, and which does not require downloading of large 
files to view satellite scenes (Jacobson et al., 2015). Hence, its use has become popular, which generates an expectation that a satisfactory real-time information will be provided. However, it is important to highlight that the frequency with which images are updated in the system may not be sufficient for more complex uses.

The vectorization of roads can generate features that no longer exist. This was evidenced by the number of roads mapped, which were considered inaccessible. In many cases, the vegetation had already occupied places initially identified as access roads. Other situations were those in which the roads were modified due to the occurrence of quagmires or gullies, creating paths next to the roads visualized in the satellite images. This can be justified by the fact that soils, largely from RPSEPA, are essentially sandy and unstructured (Dias et al., 2017), which makes roads more susceptible to erosion caused by rainfall.

The vectorization of roads from satellite images has been reported in several scientific works, and the use of images made available by GE is important in reducing the costs of obtaining data (Malarvizhi et al., 2016). The quality of mapping using GE data varies by location; however, evidence indicates that accuracy in horizontal positioning of images is suitable to work with small and medium scales (Mohammed et al. (2013), Pulighe et al. (2016), Menezes et al. (2019)).

When it comes to defining the routes to a certain tourist point, it is important to consider that the traveler has the entire travel route. Thus, a limitation is that GE cannot create routes reaching the exact location of the attraction. The lack of indication for roads in rural areas was also discussed in Coi and Nieto (2011). This was circumvented in QGIS by the vectorization of the trails and paths to these points with the help of a GNSS receiver, which clearly generates more work for data collection, but does not create insecurity in tourists when they travel a long stretch to reach their destination.

An issue related to the proper mapping of routes between different tourist spots is that this enables the planning of the use of natural resources in an optimized way, thereby reducing costs for visitors and favoring satisfaction and other intangible returns. The optimization of tourist itineraries considering certain time intervals is the subject of research, such as Zheng et al. (2017), Liao and Zheng (2018), Sirirak and Pitakaso (2018), and Zhang (2018). In the case of reliability in the results obtained, it was essential that the matrix of distances between the tourist spots be correctly elaborated.

The results of this work showed that, despite the advantages of GE software, it generated longer routes than those generated with QGIS in more than $60 \%$ of the calculated routes. Shorter routes resulted when GE could not reach the exact location of the tourist attraction. This shows that the road networks considered by GE is different from the existing ones and may compromise decision-making when more elaborate planning is needed, or when one wants to optimize the resources that must be allocated for the maintenance of roads and provide access to the places of tourist interest.

Despite offering visitors with shorter paths among tourist attractions, the road network considered from QGIS was larger than that from GE, which from an ecological point of view, is no longer appropriate. In this case, it is important to conduct new studies that assess the environmental impact caused by both situations and determine the number of routes that can be prioritized.

Thus, it can be considered that the routes obtained by GE are important when there is no recent information available about the roads in the region. For cases where such information is essential, the results show that it is necessary to conduct a thorough survey on the roads of the site.

\section{CONCLUSION}

The following conclusions are drawn from the analyses conducted:

- The Rio Pandeiros State Environmental Protection Area presents a variety of natural attractions that can aid ecotourism.

- GE images can be used for road vectorization provided that there is an on-site assessment of their conditions.

- The planning of tourist activity in an environmental protection area requires comprehensive mapping of the access roads that make up the area.

- There is a significant difference between the routes defined by the GE and those defined from the vectorization and subsequent classification of roads in the Rio Pandeiros State Environmental Protection Area.

\section{ACKNOWLEDGMENT}

The authors thank the Research Support Foundation of the State of Minas Gerais for funding this study. 


\section{REFERENCES}

CHOI, Y.; NIETO, A. Optimal haulage routing of off-road dump trucks in construction and mining sites using Google Earth and a modified least-cost path algorithm. Automation in Construction, London, v. 20, n. 1, p. 982997, 2011. DOI: 10.1016/j.autcon.2011.03.015

DANTAS, M. S.; OLIVEIRA, J. C.; PINTO, C. C.; OLIVEIRA, S. C. Impact of fecal contamination on surface water quality in the São Francisco River hydrographic basin in Minas Gerais, Brazil. Journal of Water and Health, London, v. 18, n. 1, p. 48-59, 2020. DOI: 10.2166/wh.2019.153

DIAS, L. C. C.; MOSCHINI, L. R.; TREVISAN, D. P. A influência das atividades antrópicas na paisagem da Área de Proteção Ambiental Estadual do Rio Pandeiros, MG - Brasil. Fronteiras: Journal of Social, Technological and Environmental Science, Anápolis, v. 6, n. 2, p. 85-105, 2017. DOI: 10.21664/2238-8869.2017v6i2.p85-105

FAGUNDES, N. C. A.; FERREIRA, E. J. Veredas (Mauritia Flexuosa palm swamps) in the southeast Brazilian savanna: Floristic and structural peculiarities and conservation status. Neotropical Biology and Conservation, São Leopoldo, v. 11, n. 3, p. 178-183 2016. DOI: 10.4013/nbc.2016.113.07

FRANKL, A.; ZWERTVAEGHER, A.; POESEN, J.; NYSSEN, J. Transferring Google Earth observations to GIS software: example from gully erosion study. International Journal of Digital Earth, London, v. 6, n. 2, p. 196201, 2013. DOI: $10.1080 / 17538947.2012 .744777$

HUNT, C. A.; DURHAM, W. H.; DRISCOLL, L. D.; HONEY, M. Can ecotourism deliver real economic, social, and environmental benefits? A study of the Osa Peninsula, Costa Rica. Journal of Sustainable Tourism, London, v. 23, n. 3, p. 339-357, DOI: 10.1080/09669582.2014.965176

INSTITUTO CHICO MENDES DE CONSERVAÇÃO DA BIODIVERSIDADE - ICMBIO. Painel Dinâmico de Informações do ICMBio. Disponível em: <http://qv.icmbio.gov.br/ >. Acesso em: 19/08/2020.

JACOBSON, A.; DHANOTA, J.; GODFREY, J.; JACOBSON, H.; ROSSMAN, Z.; STANISH, A.; WALKER, H.; RIGGIO, J. A novel approach to mapping land conversion using Google Earth with an application to East Africa. Environmental Modelling \& Software, London, v. 72, n. 1, p. 1-9, 2015. DOI: 10.1016/j.envsoft.2015.06.011

LEITE, H. G.; OLIVEIRA, F. L. T. Statistical procedure to test the identity of analytical methods. Communications in Soil Science and Plant Analysis, London, v. 33, n. 7/8, p. 1105-1118, 2002. DOI: $10.1081 / \mathrm{CSS}-120003875$

LIAO, Z.; ZHENG, W. Using a heuristic algorithm to design a personalized day tour route in a time-dependent stochastic environment. Tourism Management, London, v. 68, n. 1, p. 284-300, 2018. DOI: 10.1016/j.tourman.2018.03.012

LUKONGO, O. E. B.; MILLER, T. W. Data obtained with a novel approach to estimate installment loan acquisition costs. Data in Brief, London, v. 18, n. 1, p. 1257-1266, 2018. DOI: 10.1016/j.dib.2018.04.027

MALARVIZHI, K.; KUMAR, S. V.; PORCHELVAN, P. Use of high resolution Google Earth satellite imagery in landuse map preparation for urban related applications. Procedia Technology, London, v. 24, n. 1, p. 18351842, 2016. DOI: 10.1016/j.protcy.2016.05.231

MARTINSA, I.; MACEDO, D. R.; HUGHESC, R. M.; CALLISTO, M. Are multiple multimetric indices effective for assessing ecological condition in tropical basins? Ecological Indicators, London, v. 110, n. 1, p. 1-10, 2020. DOI: $10.1016 /$ j.ecolind.2019.105953

MENEZES, R. R. V.; LISBOA, M. H. M.; SANTOS, A. P.; DIAS, J. S. Avaliação da acurácia planimétrica das imagens do Google Earth para produção de base cartográfica. Revista Brasileira de Cartografia, Monte Carmelo, v. 71 , n. 2, p. 367-391, 2019. DOI: $10.14393 /$ rbcv71n2-46327

MOHAMMED, N. Z.; GHAZI, A.; MUSTAFA, H. E. Positional accuracy testing of Google Earth. International Journal of Multidisciplinary Sciences and Engineering, London, v. 4, n. 3, p. 6-9, 2013.

PADILLA, J. J.; KAVAK. H.; LYNCH, C. J.; GORE, R. J.; DIALLO, S. Y. Temporal and spatiotemporal investigation of tourist attraction visit sentiment on Twitter. PLoS ONE, Cambridge, v. 13, n. 6, p. 1-20, 2018. DOI: $10.1371 /$ journal.pone. 0198857 
PULIGHE, G.; BAIOCCHI, V.; LUPIA, F. Horizontal accuracy assessment of very high resolution Google Earth images in the city of Rome, Italy. International Journal of Digital Earth, London, v. 9, n. 4, p. 342-362, 2016. DOI: $10.1080 / 17538947.2015 .1031716$

REZENDE, R. S.; SANTOS, A. M.; GONÇALVES JUNIOR, J. F. Avaliação ambiental do rio Pandeiros utilizando macroinvertebrados como indicadores de qualidade da água. Ecología Austral, Buenos Aires, v. 22, n. 1, p. 159-169, (2012).

ROXO, F. F.; SILVA, G. S. C.; MELO, B. F. Hisonotus devidei, a new species from the São Francisco basin, Brazil (Siluriformes: Loricariidae). Journal of Fish Biology, London, v. 92, n. 1, p. 1687-1701, 2018. DOI:10.1111/jfb.13599

SANTOS, U.; SILVA, P. C.; BARROS, L. C.; DERGAM, J. A. Fish fauna of the Pandeiros River, a region of environmental protection for fish species in Minas Gerais state, Brazil. Check List, Sofia, v. 11, n. 1, p. 1-7, 2015. DOI: $10.15560 / 11.1 .1507$

SIRIRAK, W.; PITAKASO R. Marketplace location decision making and tourism route planning. Administrative Sciences, Basel, v. 8, n. 72, p. 1-5, 2018. DOI: 10.3390/admsci8040072

WEBSTER, K.; ARROYO-MORA, J. P.; COOMES, O.T.; TAKASAKI, Y.; ABIZAID, C. A cost path and network analysis methodology to calculate distances along a complex river network in the Peruvian Amazon. Applied Geography, London, v. 73, n. 1, p. 13-25, 2016. DOI: 10.1016/j.apgeog.2016.05.008

XUE, L.; ZHANG. Y. The effect of distance on tourist behavior: A study based on social media data. Annals of Tourism Research, v. 82, n. 1, p. 1-12, 2020. DOI: 10.1016/j.annals.2020.102916

ZHANG, S. Optimal planning algorithm of forest wetland tourism path based on GIS. Journal of Discrete Mathematical Sciences and Cryptography, London, v. 21, n. 2, p. 393-397, 2018. DOI: $10.1080 / 09720529.2018 .1453624$

ZHENG, W.; LIAO, Z.; QIN, J. Using a four-step heuristic algorithm to design personalized day tour route within a tourist attraction. Tourism Management, London, v. 62, n. 1, p. 335-349, 2017. DOI: 10.1016/j.tourman.2017.05.006 